\title{
Battery pack remanufacturing process up to cell level with sorting and repurposing of battery cells
}

\section{Achim Kampker $^{1} \cdot$ Saskia Wessel $^{1} \cdot$ Falko Fiedler $^{2} \cdot$ Francesco Maltoni $^{1}$}

Received: 18 October 2019 / Accepted: 2 June 2020 / Published online: 19 June 2020

(C) The Author(s) 2020

\begin{abstract}
Traditional remanufacturing is characterized by disassembly of a core up to an optimal depth of disassembly and by the replacement of some parts in order to achieve the specifications and reliability of the original product. Because of the product architecture and the reliability characteristics of electric vehicle batteries, such an approach does not recover the full residual value of battery cells. For batteries, a depth of disassembly up to cell level is necessary, but problematic because of inconvenient battery design features. Hence, an alternative framework will be presented, where each of the battery cells and the battery system key components are considered a core in itself, and the value of a remanufactured battery module depends on the combination of its cells. The product architecture and component requirements will be explained for batteries made of the three most common cell types used in the automotive industry. In addition, three solutions will be presented for the implementation of the proposed framework for remanufacturing regarding both product design and key aspects of the process chain, such as laser cutting and laser welding of battery cells.
\end{abstract}

Keywords Remanufacturing of battery packs $\cdot$ Remanufacturing of battery modules $\cdot$ Sorting and repurposing of battery cells - Electric vehicles batteries lifecycle $\cdot$ Battery cells $\cdot$ Laser welding .

Laser cutting

\section{Introduction}

The focus of remanufacturing, defined as "the rebuilding of a product to specifications of the original manufactured product using a combination of reused, repaired and new parts" [16], is

Achim Kampker, Saskia Wessel, Falko Fiedler and Francesco Maltoni contributed equally to this work.

Francesco Maltoni

f.maltoni@pem.rwth-aachen.de

1 Production Engineering of E-Mobility Components (PEM), RWTH Aachen University, Campus Boulevard 30, 52074 Aachen, Germany

2 RWTH Aachen University, Campus Boulevard 30, 52074 Aachen, Germany 
the recovery of a whole product and the prolonging of its useful lifetime with minimal additional cost [36]. An additional outcome of the remanufacturing process is its limited environmental impact [20], because of the limited input of new materials and process energy compared to the manufacturing of a new product [32]. In fact, most of the components of the remanufactured product come from the original product and comparatively little energy needs to be used for their inspection, preparation and reuse.

Such improvements in the material and energy efficiencies are welcomed by the European directive 2008/98/EC on waste [3]. However, the possibilities of battery remanufacturing are limited by the fact that the original manufacturers are responsible for the disposal of the batteries by the directive 2006/66/EC [27], so they control the market of returning cores and can impede core access to independent remanufacturers, especially on automotive batteries, where the 2000/53/EC applies as well [1]. In this work, the control of returning batteries is taken for granted, as it is the case for original equipment manufacturer (OEM). [33]

In order to reduce the effort for the remanufacturing process of most products, the core is not always fully disassembled, but only up to an optimal depth [42], which is sufficient to achieve desired reliability characteristics of the remanufactured product. This means that in modular products, not all modules are at first disassembled and then inspected, but only the ones, which, after an inspection of the assembled product, are considered subject to failure likelihood in the next useful product lifetime. [34]

This work argues that, because of the product architecture and reliability characteristics of EV batteries, the optimal depth of disassembly is up to the cell level, it provides a framework of overhaul, sort and repurpose of battery cells, which differs from traditional remanufacturing [19]. The proposed disassembly method is close to selective disassembly as proposed by [39], with the difference that, in most current batteries, the selective removal of cells damages the cells contacts. For this reason, the present work addresses the most widespread cells contacting technology of welding and proposes a method for contacting and separating battery cells by using laser welding and laser cutting, as well as designs for remanufacturing of batteries with the most common cell types, which goes one-step further to current repurposing concepts. [5]

\section{State of the art}

The circular economy of batteries for electric vehicle is mostly based on repurposing of whole battery packs, and recycling [5] but the industry interest in remanufacturing is growing, together with the need to provide battery replacements for old car models at accessible price [24]. Some independent remanufacturing companies already remanufacture batteries of hybrid vehicles, mostly based on Nickel-metal hydride cell chemistry and not welded cell contacts. Nissan already mass produces remanufactured Lithium-Ion batteries for its Leaf, which has a special design with very small modules and bolted connections. Furthermore both Toyota and Johnson Controls have registered process specific patents for remanufacturing of batteries [37, 40] and Tesla announced it will remanufacture the battery pack of the Model 3 at module level; however there is currently no industrial application of remanufacturing up to cell level of batteries with Li-Ion cell chemistry and welded cells, as the state of the art of the most current EV models are. In fact, while the first electric car batteries were assembled in small volumes and bolted connections where acceptable, the demands of high volume manufacturing for stable and fast processes, as well as small and less variable contact resistance, are better met by welding [6]. 
The potential to extend the lifetime of Li-Ion batteries and to restore the state of health (abbreviated $\mathrm{SOH}$ ) to almost $100 \%$ by exchanging a small number of cells has been demonstrated in theory by simulating the reliability properties of battery cells and by virtually replacing the worst aged cells of a battery pack [25]. The present work confronts the problem of making that concept viable in practice, by addressing the issues which prevent an easy disassembly of battery packs and reuse of cells.

The whole idea of cells sorting and repurposing is based on the concept that only few cells are actually degraded when the battery reaches its end of life. The simulation by Mathew et Al. [25] estimates that the replacement of 5-30\% of the cells can bring a battery system at a state of health (abbreviated $\mathrm{SOH})>95 \%$. A simplified representation of these findings is in Fig. 1.

The Batteries do not fulfill all the criteria for products capable of being remanufactured [15] and some challenges are still not solved [26].

The product architecture of automotive batteries is apparently mostly modular, as it is characterized by some modules which are responsible for specific functions (such as battery management, safety connection and disconnection, as well as cooling), and of several other modules which contain the battery cells, responsible for storing energy. Most of the economic value of the battery is in the cells and in some electronic components, whose recovery requires high depth of disassembly. A schematic product architecture is shown in Fig. 2.

One of the purpose of modular design in the field of system reliability is to condense the functions that have similar failure rates or maintenance intervals in a module, in order to facilitate the replacement of the failed or worn components, by replacing the module, without completely disassembling the product.

As it is possible to replace the energy storage modules of a battery, which are going to fail first, this purpose is apparently fulfilled. As each modules fails (because of either reduced capacity, increased resistance or other failure) when the weakest cells fail, the same feature would be desirable among the cells of the same module, otherwise a module become useless

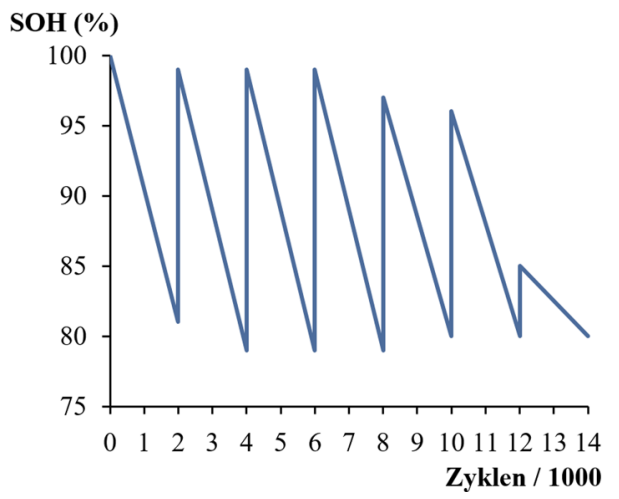

\footnotetext{
Mathew et Al. simulated the state of health of a battery system, where all the cells with SOH $<85 \%$ would be replaced when the battery reaches $\mathrm{SOH}<80 \%$. This proves that remanufacturing of batteries could restore the batteries to an almost "as new" state, with replacement of a relatively little number of cells.
}

Fig. 1 State of Health of a battery system with cells replacement Mathew et Al. simulated the state of health of a battery system, where all the cells with $\mathrm{SOH}<85 \%$ would be replaced when the battery reaches $\mathrm{SOH}<80 \%$. This proves that remanufacturing of batteries could restore the batteries to an almost "as new" state, with replacement of a relatively little number of cells 


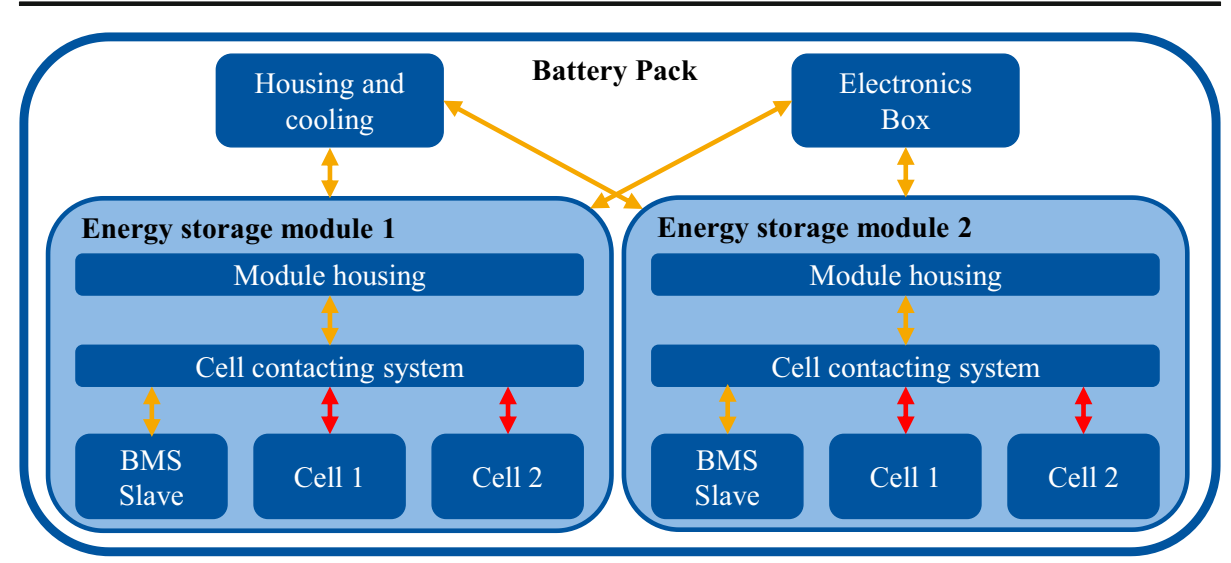

EV Batteries have a modular structure, with electronics as well as many energy storage modules.

Fig. 2 Product architecture of a battery pack EV Batteries have a modular structure, with electronics as well as many energy storage modules

when most of its cells are still functional and will last longer. This can be seen by looking at the Weibull distribution of the failure probability function for a single cell (assuming for simplicity that all history dependent variables are fixed), and of an array of cells in parallel.

$$
\mathrm{p}(\mathrm{x})=\frac{\beta}{\alpha \times \beta} t \times \beta-1^{\frac{-t}{\alpha} \times \beta} \text {, where } \beta>2
$$

For $\mathrm{n}$ cells in series, the shape constant $\beta$ stays constant but the scale factor decreases $\alpha \mathrm{n}=\alpha 1$ / $(\mathrm{n})(1 / \beta)$ compared to that of a single cell, as qualitatively shown in Fig. 3. This explains why most of the cells are still functional when the battery has failed or does not satisfy its requirements. Please note that the area under the curve represents a total failure probability of one, as no cell has an infinite life.

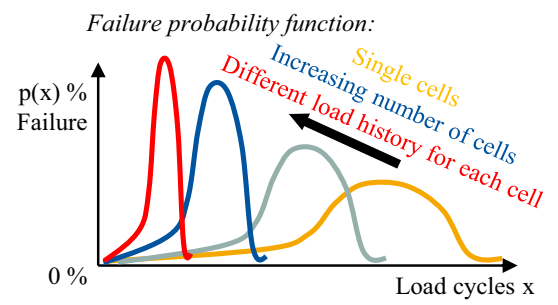

Failure probability function of a battery system could be modelled as a Weibull distribution, if all the cells had the same history. Since this is not the case because every cell has a different capacity, it experiences a different Depth of Discharge during each cycle, which affects aging differently as well as the temperature inhomogeneity. These in in homogeneities increase the probability that the battery failure will be sooner, rather than later.

Fig. 3 Failure probability function of a battery system Failure probability function of a battery system could be modelled as a Weibull distribution, if all the cells had the same history. Since this is not the case because every cell has a different capacity, it experiences a different Depth of Discharge during each cycle, which affects aging differently as well as the temperature inhomogeneity. These in in homogeneities increase the probability that the battery failure will be sooner, rather than later 
Additionally, each cell experiences a different load history: in fact the temperature inside the battery pack is not homogenous, the cells with less capacity experience more depth of discharge than the ones with more capacity. Moreover, when cells are in parallel, the cells with less internal resistance experience more current, hence more heat generation, than the ones with more internal resistance. Lehner pointed out in her experimental research how the different positions within battery packs causes different aging. In general, these effects are independent of the failure probability under homogenous conditions, so the failure probability of the whole system increases furthermore, as likely the weakest cells will be loaded the most. [23]

For these reasons, the replacement of failed energy storage modules of a battery pack solves the problem of battery reliability only partially, that is it reduces the number of cells in series, which can fail independently to the number of cells of each module. By dividing the cells of a battery pack in modules which can be replaced, the expected life of a module can be longer than the battery pack life by a factor $1 /(\mathrm{n} / \mathrm{m})(1 / \beta)$, which makes a point for replacing failed battery modules. This way the battery packs can be maintained according to a traditional remanufacturing lifecycle, where modules are replaced, as long as these fulfill the requirements of new modules. [35]

New ones would replace the modules, which do not fulfill the specifications of new ones, and the remanufactured battery packs will fulfil the specifications of the original product.

Another important aspect is that the remanufacturing relies on the concept of End-of-Life decision, whether cores or components can be reused or must be recycled based on the comparison with new product specification or on the expected residual life [28]. In the case of Lithium-Ion battery cells, this task is not easy and not completely solved yet, because they are subject to several concurrent degradation mechanisms. [38]

These aging mechanisms have been widely researched under lab conditions [14], and depend on the calendar life and on the use history of the battery cells [28], so the availability of the battery use data would allow relatively accurate predictions on the battery degradation [4]. Since at the moment such data are either not saved on electric vehicles batteries, or not available to independent remanufacturers, the End-of-Life decision must be made only by testing incoming cores as they are after the recovery.

Some methods to detect the progression of battery aging are available [4], but these methods are not yet viable as End-of-Life decision tests for cells and modules, because of the destructive nature of the necessary tests, or their long duration, which makes them hardly scalable. Particularly difficult is the test of single cells before the module disassembly, where only the presence of degraded cells in the module under load can be detected, but not the $\mathrm{SOH}$ of the single cells. [11]

The aging properties of the cells affect the reliability of the whole battery system, which has been studied statistically by Lehner [23].

Each battery module houses plenty of single battery cells, which are parallel or serial connected by electrical cell connections [12]. Cell connections differ by the battery cell type, how the electrodes are designed at the battery cell housing, and if additional connectors (bus bars) are needed. Cylindrical battery cells have a negative and positive cell terminal on both ends of the cylindrical form and are mainly made of steel. Prismatic battery cells have a negative and positive cell terminal at the outside of the cell housing. Both cell terminals are mainly made of aluminum and thus enables a similar cell connection with aluminum bus bars. Pouch battery cells have two thin, flat, and long sheet electrodes, called cell tabs. The positive electrode is mostly made of aluminum and the negative electrode is made of nickel plated 
copper. The cell tabs can be used to bridge the distance between battery cells and thus the opportunity to connect battery cells without additional bus bars. [12, 24].

The aim of battery cell connection is to achieve the highest possible electrical conductivity between battery cells by keeping the contact resistance between the joining partners as low as possible. [31] Ideally, all joints of the cell connections should have a constant value in order to prevent uneven loading of the battery cells during operation, especially with parallel connected battery cells. [29] High priority is also given to the reliability of the cell connection over the entire lifetime of the battery. The cell connectors must be able to safely withstand the dynamic loads in the car. Brittle behavior of the connection must therefore be avoided. The already heavy battery pack should not be made even heavier by additional elements, such as bus bars. Therefore, a light connection without additional elements should be preferred. Moreover, the available installation space should not be restricted too much by cell connection. [6, 12].

The cell contacting and thus connecting of battery cells represents a serious challenge in battery systems and especially for the joining technology. Challenges for joining are caused by the highly heat-conducting materials, such as aluminum or copper, which can result in dissimilar joints, multilayer materials, and different thicknesses. Current research focuses on the aspects of lightweight construction (mass of the connecting elements), production (production time) and function (electrical resistance). [18]

According to DIN norm, joining is determined by a permanent connection of one or more stable parts with a geometric shape with or without additional shapeless material for joining [2]. Mechanical joining technologies, such as screwing and thermal joining technologies, such as resistance welding, ultrasonic welding, and laser welding are particular used for battery cell connection. [8, 22] Many cell connections are bolted, which have disadvantages in additional weight and higher contact resistance, as well as high cost and long assembly time. Advantages are the good demounting properties, standard technology, and the fact that no heat is introduced during joining. Thermal joining processes realize a material-locking connection with lower electrical contact resistance and their high connection quality over the service life $[8,29,30]$, as well as a fast process in the assembly line and high degree of automation. Resistance welding has so far mainly been used for joining cylindrical battery cells. It is a fast and easily automated process, but has weaknesses in the case of electrically and thermally highly conductive aluminum and copper materials. Ultrasonic welding is very well suited for pouch cells with dissimilar cell tabs due to low welding temperatures and easy automation. However, disadvantages are seen in the limitation of the maximum possible joint thickness, joint strength, and flexibility by both sided accessibility. Laser beam welding is considered the optimal joining method for some applications in battery production, due to the high beam intensity, high-precision beam control, and high process speed. Difficulties can occur on dissimilar materials, such as aluminum with copper of bus bars and cell terminals. Dissimilar joints tendency form intermetallic phases and can lead to embrittlement of the weld seam. Moreover, there is still thermal impact on the surrounding parts and the joints are not demountable. Qualified staff is needed for running a laser welding cell and the investment costs are comparatively high. On the other hand laser beam welding offers great potential due to good automation and high system availability. High process speed and multi-station operation are possible, which benefits economic production and thus meets the growing demand for efficient battery production. The fact that only one-sided accessibility is necessary and that remote joining takes place without contact also have a positive effect on the cycle time and possibilities in component design. 
The norm DIN8580 classifies separation technologies of manufacturing processes in primary shaping, material forming, separating, joining, modifying material property and coating. Regarding to the process for battery pack remanufacturing it is useful to focus on the category of separating. Dividing through mechanical processes like shear cutting or machining processes such as sawing are not effective to fulfill the expectations of cutting in this context as a change in the shape implicates a redesign of cutting tools and thus causes high costs and effort. [21]

The processes within the group of material removing are not based on mechanical core principles either, but on thermal, chemical and electro-chemical material removing. [10] Aiming for flexibility and automation in production these contactless processes are inevitable for further investigation.

The contactless separation technology laser cutting is classified among the thermal material removing, which enables a high automation due to the potential of high-speed operating, of accuracy and its wear-free characteristics [15]. Another process type is remote laser cutting, which works without the support of any gas in the cutting process and without direct contact to the work piece. The cutting geometry can be adapted by programming and is able to cut various meters per second [14]. Nevertheless, problems like heat dissipation caused by thermal conductivity or suppressing of localized heating because of reflectivity of the material should be considered. Furthermore, the laser cutting process depends highly both on the adequate selection of the laser parameters and the work piece material properties [41].

To summarize, in order to economically remanufacture batteries, it requires design features like the widespread use of electrical contacting technologies such as welding [9], as well as joining technologies like gluing and the use of heat conductive paste. It is also necessary to offer a guarantee on remanufactured batteries, which is translated into the necessity of predicting the residual life of cells and set acceptance criteria on cells and modules for the reuse in remanufactured batteries [5].

The most accurate End-of-Life decisions could be made on used single cells the single cells, especially if use history data were available, so it is important to develop methods to disassemble batteries up to cells level.

\section{Methods}

The present work first attempts to confirm the underlying hypothesis of the simulation Mathew et al. about the fact that most cells of a used battery packs are indeed worth recovering. Then it addresses the topic of separating welded cells without damaging them and without compromising the performance or the welding process.

On the basis of the results, it lays out a possible lifecycle for cells and presents designs which make use of such joining methods.

\section{Experimental confirmation of cells reliability}

In order to confirm the underlying hypothesis to the simulation of Mathew and Kong, the cells of the 18,650 type recovered from a module have been separated and tested by means of cycling between safe voltage limits: the cells are 196 and are nominally rated between 2800 $\mathrm{mAh} 4.2 \mathrm{~V}$ and $2.7 \mathrm{~V}$. The module has been taken from the battery of a StreetScooter vehicle 
has been used by Deutsche Post for six month, two deep cycles per day, six days per week within the research project BatteReMan.

$89 \%$ of the cells are still reusable, $9 \%$ have an insufficient capacity for reuse, and $2 \%$ have some other kind of failures, such as unstable voltage, high internal resistance or cause errors in the test equipment; it is possible that those cells have been damaged during the disassembly process. A summary can be seen in Fig. 4

The capacity test has been carried out between $4 \mathrm{~V}$ and $2.8 \mathrm{~V}$ to fit the test into the available time slot; because of this time constraint the constant voltage time has been limited to $5 \%$ of the whole charging time, hence the shown capacities are lower than those of new cells. The tests confirm qualitatively the assumption of Mathew and Kong. The distribution of the useful capacities is in Fig. 5.

Of the still reusable cells, $68 \%$ are still probably useable for automotive applications, $16 \%$ only for stationary applications, and $5 \%$ are probably not worth being reused, even if technically are not failed.

\section{Cutting of used battery cell contacts and battery module frames}

As part of the remanufacturing process, the identified battery cells needs to be safely removed from the battery module. This process step is crucial due to close process operation on the battery cells and its potential danger of damaging. Several separation technologies can be basically used with respect to the six manufacturing processes of DIN8580 norm. The requirements of the cutting process are mainly determined by the battery cell and the battery module design for remanufacturing. Impacts of the cutting process on the battery cell, such as temperature at the cell housing, mechanical forces on the cell terminals, loosen parts of the cut cell connection, burr formation at the cell terminal needs to be investigated. Besides this, the
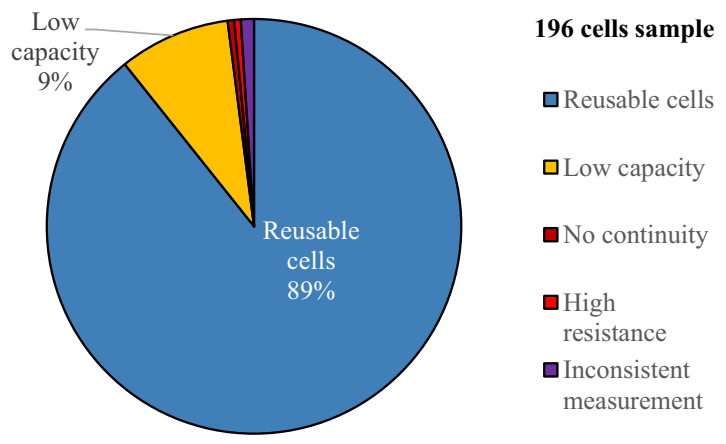

Most of the recovered cells from a battery module are still reusable. About $10 \%$ show either low capacity and cannot be charged to the nominal voltage because of aging, and a very small quantity of cells shows no continuity between positive and negative terminals, or unsteady measurement values. Probably these last group of cells have been either damaged during the disassembly process, or suffered severe failures in use.

Fig. 4 Status of recovered cells from a module in the project BatteReMan. Most of the recovered cells from a battery module are still reusable. About $10 \%$ show either low capacity and cannot be charged to the nominal voltage because of aging, and a very small quantity of cells shows no continuity between positive and negative terminals, or unsteady measurement values. Probably these last group of cells have been either damaged during the disassembly process, or suffered severe failures in use 
Capacity of 2800 Ah round cells 18650 after two years of heavy

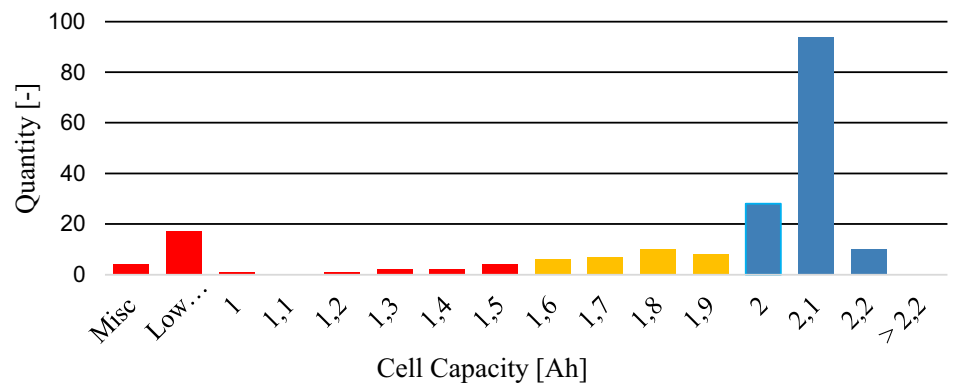

The distribution of cells capacity confirms the assumptions of Mathew and Kong. In fact, most of the cells are still reusable, while a small part show accelerated aging. The capacities here are less than the nominal ones, as they were measured only between state of charges relevant to the automotive use, in this case between $4 \mathrm{~V}$ and $3 \mathrm{~V}$.

Fig. 5 Capacity distribution of cylindrical cells recovered in the BatteReMan project The distribution of cells capacity confirms the assumptions of Mathew and Kong. In fact, most of the cells are still reusable, while a small part show accelerated aging. The capacities here are less than the nominal ones, as they were measured only between state of charges relevant to the automotive use, in this case between $4 \mathrm{~V}$ and $3 \mathrm{~V}$

cutting process needs to fulfill economic aspects and be suited for automating to series production. Moreover, the cell connection must fit after the cutting process the requirements for a subsequent joining of a new cell connection. This is especially crucial, if the cutting process directly affecting the new joining area and therefore has additional requirements on the cutting process. Remote laser beam cutting with and without additional cutting gas has been used for the experiments. Design for remanufacturing can implement this requirement by having two or more joining areas within the battery cell terminal, whereby the initial battery production just use the first joining area. The same principle can be used for the battery module housing.

\section{Joining of battery cell contacts and battery module frames}

Many joining technologies, such as resistance welding, laser welding, arc welding, and screw connection are already in application for joining of battery cell contacts as well as battery module frames. In comparison of these technologies, laser has a high potential for series production due to its high process speed, only one side accessibility, and high local energy density, which enables welding of different kinds of metal.

In this research, a disc laser with $4 \mathrm{~kW}$ laser power in combination with a programmable focusing optic has been used for the experiments. The optic has a focal distance of $450 \mathrm{~mm}$ and can move the laser spot with a velocity up to $1 \mathrm{~m} / \mathrm{s}$. For validating of the presented remanufacturing concepts without danger, dummy battery cells have been used to produce dummy battery modules for investigating the processes without danger. As part of the methodology, all relevant laser parameters have been previously investigated and validated by performing experiments on specimens. This enables to perform experiments with necessary sensors and accessibility on a certain amount of specimens. The laser parameters under investigations have been the laser power, laser speed, spot size, laser power, ramp functions, 
and the laser welding seam geometry. Relevant measured data on the specimens are the temperature at the battery cell transition, the maximum tensile force of the welding seam, resistance of the welding seam, welding seam quality by visual testing, and cross-section of the weld seam.

For performing experiments and producing active battery modules, a special safety device is currently developed. The device is needed for the event of an unexpected thermal runaway, where the battery module needs to be cooled down as fast as possible. Moreover, the device can evacuate the toxic gas, collect as well as neutralize the electrolyte, reduce the risk of secondary fires, and smoothly discharge the entire battery module.

\section{Results}

\section{Overhaul of battery packs, Sort and repurpose of battery cells}

Battery remanufacturing by the replacement of old, out of specifications battery modules with new modules is not the best strategy to use the rest value of a used battery pack. In fact, the new modules are expensive to buy, and the old modules, which are likely to fail sooner, as they have a longer history of calendar and cyclical aging, will probably determine the reliability of the remanufactured battery pack. Ideally, the battery modules should be replaced by ones, which have a similar useful life expectancy to the ones staying in the battery pack.

This is not possible, because each module has a different life expectancy, which is very difficult to predict. Nevertheless, the modules can be individually tested by capacity measurement, internal resistance and self-discharge current then accordingly classified. Therefore, it is possible to build battery packs of homogeneous modules, thus optimizing reliability and performance on one side and the value of the used modules.

Nevertheless, some modules can seem functional after a first, superficial, analysis, but might have some cells, which show some signs of deteriorating fast, so it is important to identify such cells. Here a diagnostic method to identify the modules with deteriorated cells is needed. An electrochemical impedance spectroscopy performed on a module can be a first method of screening for very evident deterioration signs of single cells, but its sensitivity decreases with the total number of cells in series or in parallel in each module [11].

The majority of the modules with a few degraded cells could still have a high residual value, if the cells could be recovered sorted and reused, hence the need to develop industrial processes to recover such cells in a functioning state, to test and sort them, and to use them in the same process chain which manufacture new batteries. This way, the uncertain number of cells from returning batteries, could be used to manufacture new safe battery products, without requiring extra investment and contributing to improving the assembly line capacity utilization.

For this reasons the lifecycle of a battery system will be as in Fig. 6:

\section{Design of Battery Modules for overhaul, Sort, and repurposing of battery cells}

In order to achieve battery cells recovery from used modules, the following requirements on the product design are necessary [17]: 


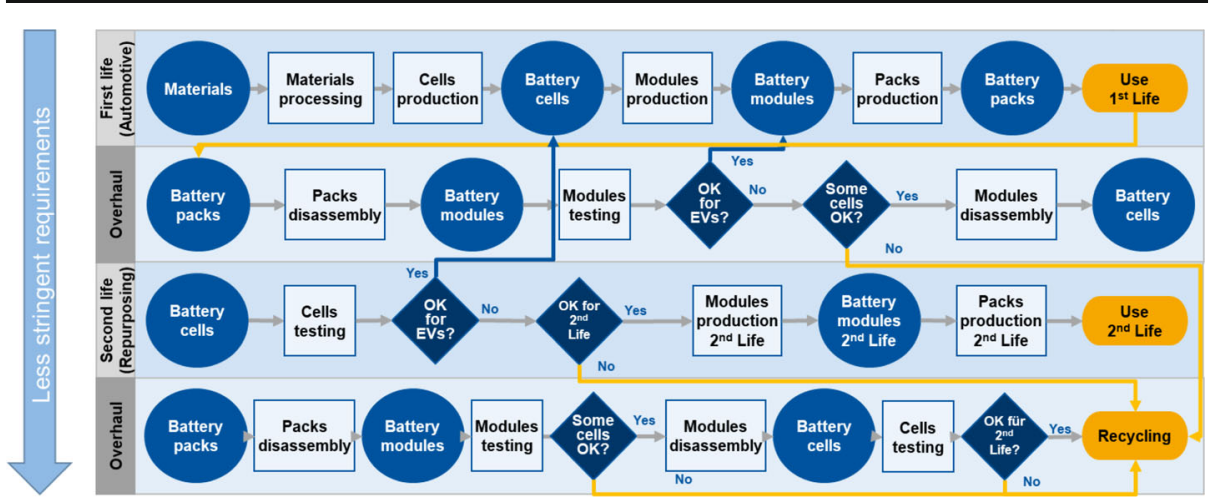

Block diagram of the proposed process for battery pack remanufacturing as well as overhaul, sort and repurposing of battery cells

Fig. 6 Lifecycle of battery packs for the optimal use of cells residual value Block diagram of the proposed process for battery pack remanufacturing as well as overhaul, sort and repurposing of battery cells

1. Cell connections or busbars with no higher electrical resistance than on state-of-the-art batteries

2. The components must be assembled without glue, due to difficult separation

3. The parts which are lost in the disassembly process must be easily separated

4. The assembly process must be capable of being automatized

5. The disassembly process must be capable of being automatized

6. Danger of causing short circuits during the disassembly must be prevented

7. Safety concept in case of a thermal runaway of battery cells

8. Voltage and temperature sensors, as well as wiring harness, must be removed easily

9. Weight and packaging requirements must be comparable to state-of-the-art batteries

With respect to these requirements, battery designs have been developed, together with their respective assembly and disassembly processes for each type of battery cells available for the automotive use: prismatic, cylindrical, and pouch cell.

\section{Design of Battery Module with prismatic battery cells}

Based on a current widespread design of a battery module with PHEV2 standard prismatic cells (dummies), a half-scale prototype shown in Fig. 7 has been developed, which fulfills the same functions and product architecture. This way it has been possible to investigate the remanufacturing process without danger.

The main difficulties of disassembly the mass produced battery module to cell level are:

1. Welded aluminum busbars between the battery cells

2. Welded side plates to the pressure plates, whose removal is dangerous for the cells

3. Isolation between cells and housing by means of a thermoformed and glued polyethylene film, which is difficult to completely remove and clean

4. Very strong adhesive (probably cyanoacrylate) is used between the battery cells. In this cases it is not possible to separate the cells (Not on the reference module, but on other similar modules) 


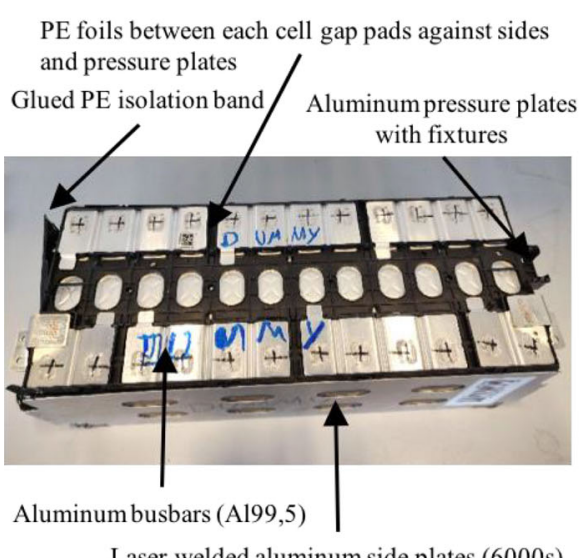

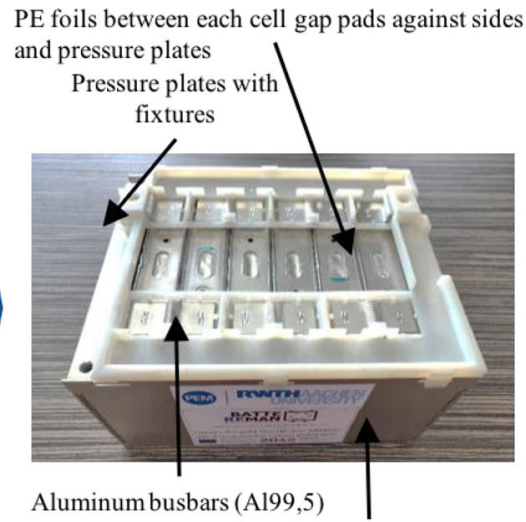

Aluminum side plates $(6000 \mathrm{~s})$

Based on the conventional mass produced battery module (left side), a prototype battery module (right side) has been derived for setting up the remanufacturing process

Fig. 7 Comparison between a conventional traction battery module and the BatteReMan demonstrator module with prismatic battery cells Based on the conventional mass produced battery module (left side), a prototype battery module (right side) has been derived for setting up the remanufacturing process

In the disassembly of conventional modules, the welded module housing is destroyed, but it can be cleaned and recycled as 6000 series Aluminum without being downcycled. New parts can be easily built through cutting processes, such as stamping as well as laser cutting and forming by deep drawing as well as sheet metal bending.

The isolation films must be replaced as well, which poses a minor problem on the stack height tolerances, which affect the position of the module fixture holes, and the pressure of the cells in the housing. For that reason, a welding jig is during reassembly used, which impose the position of the pressure plates, and the stacking force is measured and checked by a dynamometer. This force is to be expected higher than on the original module, because of battery cell aging. Slightly thinner isolation films could compensate for that and make sure that the cells experience the optimal pressure for aging in the remanufactured module [7].

The printed circuit board (abbreviated PCB) with all the voltage and temperature sensors, is not represented in the pictures, and, at the moment, is not reused but replaced by a wiring harness and thus represents a further field of research. A part from the possibility of a very strong adhesive between the cells, the recovery of undamaged cells from such modules have been proven possible.

Nevertheless some changes to the remanufactured modules have been implemented to facilitate the remanufacturing operation:

1. The pressure plates have a slot besides the 1st weld seam for laser cutting the side plates off. A new designated area for welding is besides the slot, which was before under the first side plate. This is exemplified by laser cutting in Fig. 8 .

2. The busbars of the determined battery cells from the first life modules are cut, which is shown in Fig. 9.

3. Exchanging and sorting the battery cells for the 2nd life application

4. Welding of the busbars on top of 1st life busbars, with minimal increase in the module height, as shown in Fig. 10. 


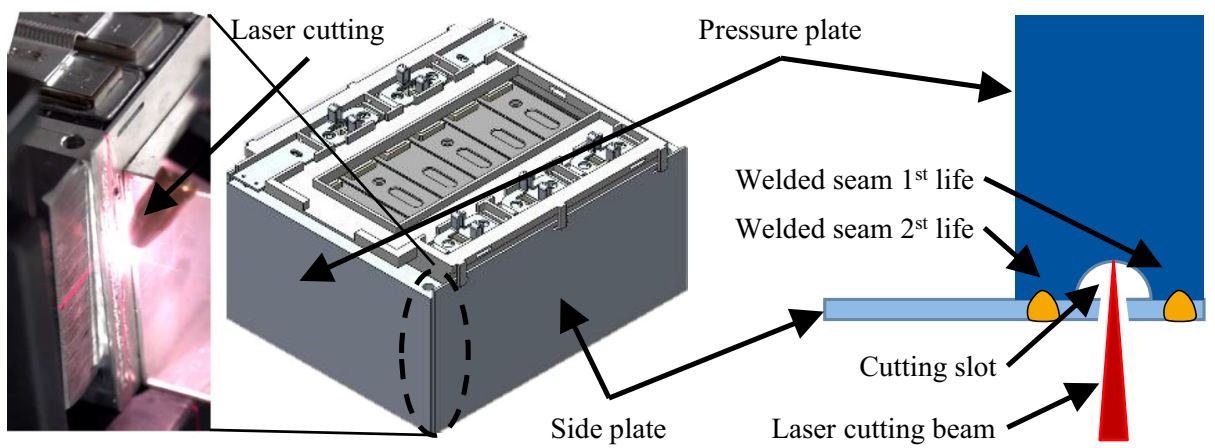

The side plates of the battery module frame have been cut close to the pressure plates to recover the cells. After replacing battery cells for $2^{\text {nd }}$ life application, the same side plates are welded again with the same pressure plates at a different nearby welding area

Fig. 8 Laser cutting and design details for the battery module side plates The side plates of the battery module frame have been cut close to the pressure plates to recover the cells. After replacing battery cells for 2nd life application, the same side plates are welded again with the same pressure plates at a different nearby welding area

5. The carrier of the wiring harness, or a new flex PCB has a different height, in order to accommodate a wiring harness on a higher level because of the two busbars

\section{Design of battery module with cylindrical cells}

During the research project BatteReMan, sponsored by the European Regional Development Fund, a battery module with cylindrical cells has been designed and disassembled for remanufacturing.

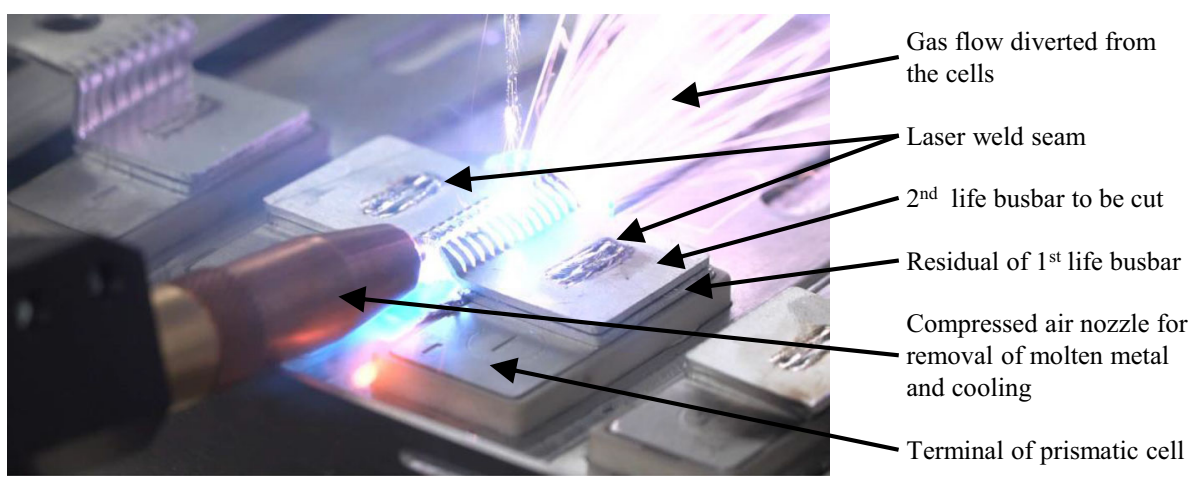

Laser cutting of busbars with process cutting gas. A tool is put under and between the busbars to collect the molten metal and protect the cell housings. Protective gas cools down the busbars and the cells during the process, and removes debris from the module.

This module has been remanufactured already once, as two layers of busbars are visible.

Fig. 9 Laser cutting for 2nd life busbar Laser cutting of busbars with process cutting gas. A tool is put under and between the busbars to collect the molten metal and protect the cell housings. Protective gas cools down the busbars and the cells during the process, and removes debris from the module. This module has been remanufactured already once, as two layers of busbars are visible 


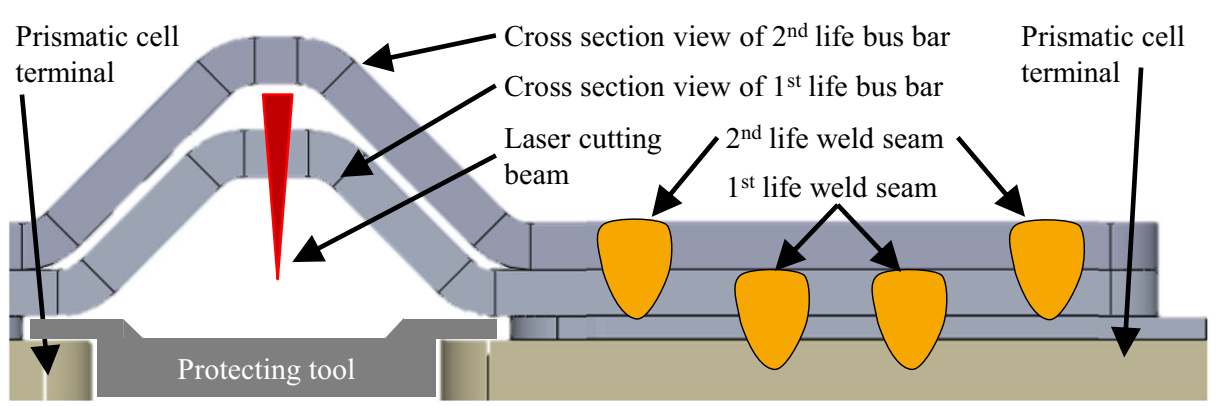

The cell connecting busbars are cut during disassembly by using laser beam; an isolating tool protects the cells from debris of molten metal and the laser beam. The surface of the busbars is then polished and a new busbar is welded on top.

Fig. 10 Laser cutting and welding for 2nd life busbars on top of 1st life busbars The cell connecting busbars are cut during disassembly by using laser beam; an isolating tool protects the cells from debris of molten metal and the laser beam. The surface of the busbars is then polished and a new busbar is welded on top

The main difficulties of disassembly the original product to cell level are:

1. Spot welded nickel plated steel cell connectors

2. Cell holders made of two parts, each of which fixes the current collectors by means of hot pressed pins. Thus the removal of the current collectors destroys these elements

3. The orientation of the cells with two rows facing up with the plus terminals, and the two next rows with the minus terminals facing up. This way the cell connectors can be flat, but the drawbacks are:

a. Plus terminals facing other cells can facilitate the propagation of a thermal event

b. Inhomogeneous cooling because the minus terminal has an higher effective surface for cooling

4. Connections between current collectors and busbars are glued with epoxy resin, to prevent corrosion, among others

The cells could be recovered manually with a high percentage of success, as well as the lightly glued gap pads and busbars, but both the current collectors and the plastic cell holder have been destroyed. However, the destructive process was such that these components could be recycled without contamination.

By the replacement of the destroyed components with new ones, it has been possible to remanufacture the original module design; nevertheless, a specific design for remanufacture has been proposed with the following features, shown in Fig. 11:

1. The nickel-plated cell connectors are designed for elastic deformation, so that they compensate tolerances in the direction of cell axes. This is needed for cell contacting and ensuring zero gap for laser welding. Moreover, they have gaps, which allow safe venting, in case of thermal events. The cell joining has been made by laser welding with multiple spots, in a favorable pattern for easier removal for later remanufacturing.

2. One single cell holder holds all cells for a parallel connection in a sub-module. Such sub modules can be quickly exchanged allowing a very easy module remanufacturing at a 


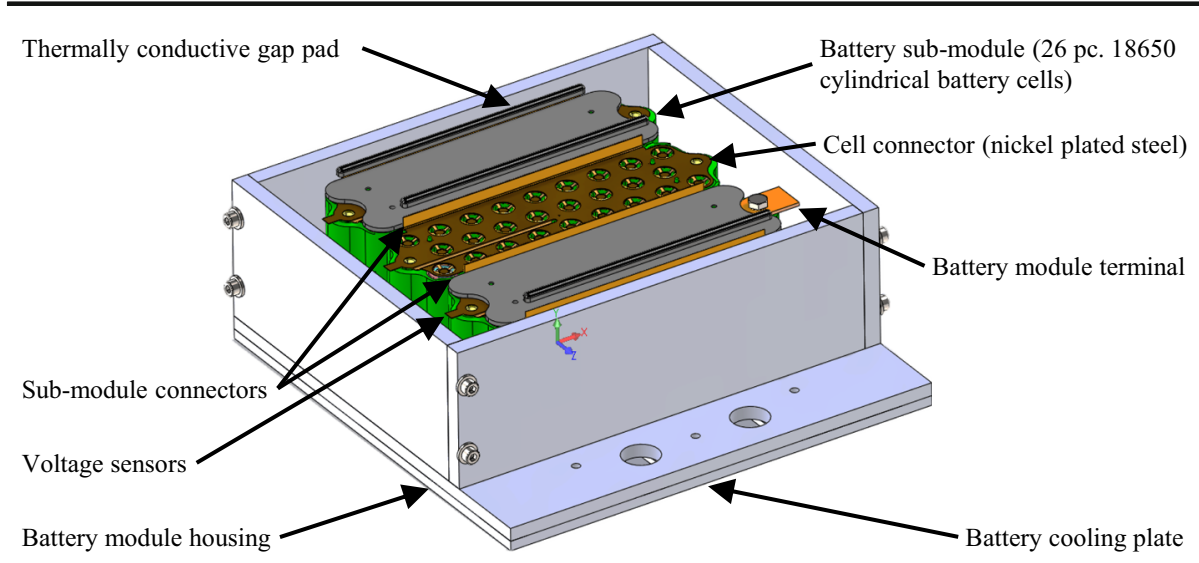

The module in the figure is divided in sub-modules, each of them contains as many parallel contacted cells as needed and has one voltage sensor. All the submodules are connected in series.

The cell collectors are kept in place by thermally conductive gap pads, which isolates from the cold plate on the negative terminal side.

Fig. 11 Battery module architecture with clyindrical cells The module in the figure is divided in sub-modules, each of them contains as many parallel contacted cells as needed and has one voltage sensor. All the submodules are connected in series. The cell collectors are kept in place by thermally conductive gap pads, which isolates from the cold plate on the negative terminal side

lower depth of disassembly than the module, but higher than the cells. All the parallelconnected cells can be seen by the BMS as one big cell, so these sub modules can be easily diagnosed on line.

3. Each cell is oriented with the minus terminal in the same direction, where a cooling plate can be placed, isolated from the terminal by a gap pad. The plus terminals can be isolated by another gap pads against a cover, which has the function of evacuating venting gases without propagating to adjacent cells, as shown in Fig. 12.

4. The same orientation of the cells implies that the sub-module connector must conduct the current from the bottom of the first sub-module to the top side of the second submodule. This implies a slight weight and dimension increase. The sub-module connectors are laser welded on the top side of a joining area and is furthermore designed for laser cutting and laser welding for 2nd life application, as can be seen in Fig. 13.

This remanufacturing design has been proved to withstand at least three remanufacturing processes on dummy cells because of the special design of the welded joints, as in Fig. 14.

In this way, the terminals of used cells can be cleaned and the remanufactured joints have the same electrical resistance as the original ones because of many welded spots, and are very good. Moreover, the use of many small welding spots limits significantly the heating of the active materials inside the cells, in comparison with resistance spot welding. As the Fig. 15 shows, the electrical resistance decreases very slowly with the laser power, but the mechanical resistance increases quite steeply up to a maximum. However, neither of the electrical and mechanical optima can be reached, without increasing the cells temperature to dangerous 


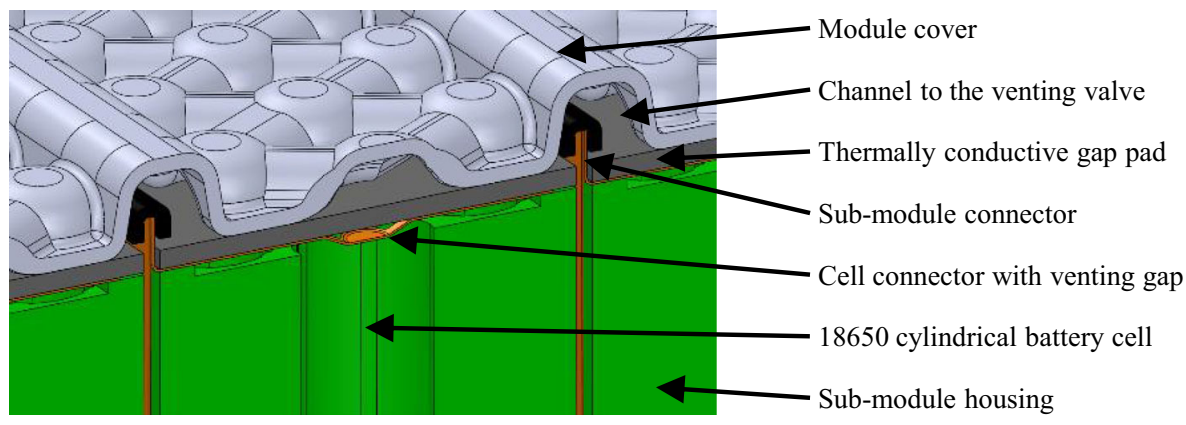

A plastic shaped cover closes the module on the positive side and limits propagation of a thermal runaway event in one of the cells. In fact, the hot gases coming from the positive terminal of one

cells quickly melt the gap pad and diffuse through the channels, where they cool down by expansion, and are conveyed to the venting valve through the channels. Since the gases move on the top side of the gap pad, the propagation is limited.

Fig. 12 Cover of the module architecture with cylindrical cells A plastic shaped cover closes the module on the positive side and limits propagation of a thermal runaway event in one of the cells. In fact, the hot gases coming from the positive terminal of one cells quickly melt the gap pad and diffuse through the channels, where they cool down by expansion, and are conveyed to the venting valve through the channels. Since the gases move on the top side of the gap pad, the propagation is limited

levels, so the proposed approach aims at achieving a very good electrical resistance and a sufficient mechanical resistance by optimizing the number of welding spots.

Because of the difficult measurement of the electrical resistance on production cells, the quality assurance is made by destructive tests on samples on each production batch, and the mechanical pulling force is measured as an indirect indicator of a good connection. Because of the statistical dispersion between these two values, higher energies than needed are usually employed. Hence the adoption of welded joints designed for remanufacturing is conditioned by the development of better quality assurance methods, which do not rely on high pulling force. Such development is to be expected, as non destructive tests need to be developed, and

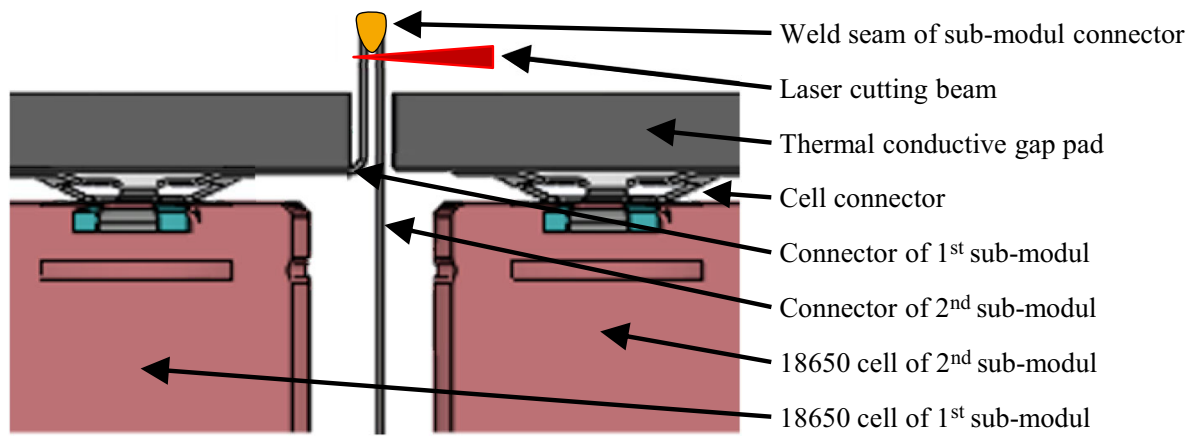

The sub-module connector from the negative side of a submodule is laser welded to the positive one of the next sub-module. The welded seam is accessible when the module is open, can be removed and welded again by means of special tooling.

Fig. 13 Laser cutting and laser welding between two sub-modules The sub-module connector from the negative side of a submodule is laser welded to the positive one of the next sub-module. The welded seam is accessible when the module is open, can be removed and welded again by means of special tooling 


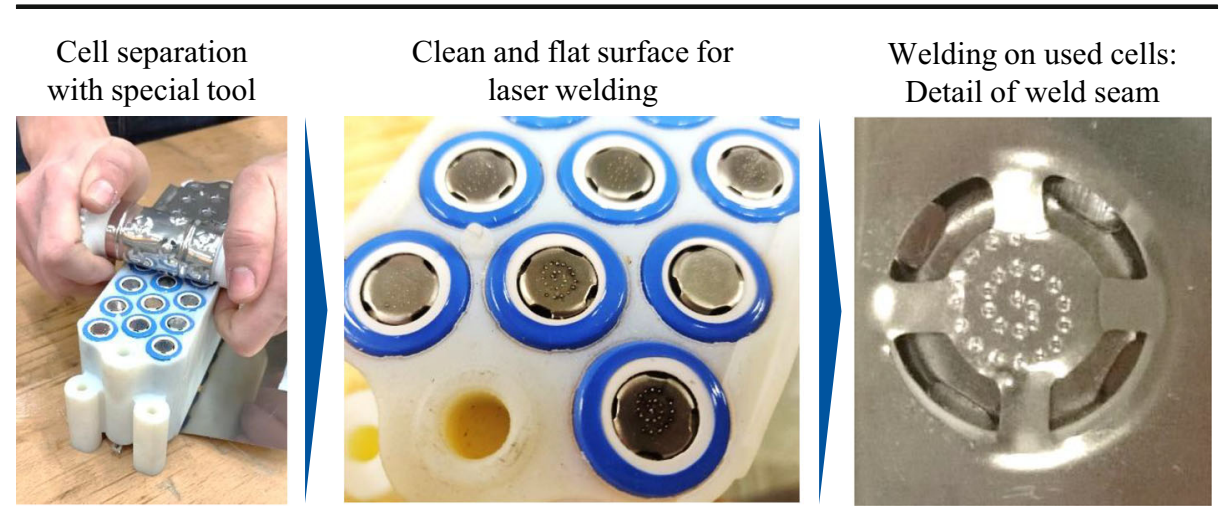

The special joint shape is designed to overload one welding spot at a time, while the tool for

the separation of the current collectors keeps the other ones in contact, thus preventing deformation of the cells terminal. The current collector are designed to compensate for tolerance and allow the tool to exert pressure on the welded joint.

Fig. 14 Separation of battery cells from sub-modules and detail of welding seam The special joint shape is designed to overload one welding spot at a time, while the tool for the separation of the current collectors keeps the other ones in contact, thus preventing deformation of the cells terminal. The current collector are designed to compensate for tolerance and allow the tool to exert pressure on the welded joint

the limitation of cells temperature during welding is a development objective, independently of remanufacturing.

\section{Design of battery module with pouch cells}

Designs with pouch cells are the most challenging for the cells recovery, in fact the pouch cells have no stabile shape and are very delicate; the main obstacles to the non-destructive disassembly of pouch cells modules are:

1. The cells are often glued to one another, to overcome the positioning difficulties and the quite large tolerances of the cells, in particular their stacking.

2. Moreover, they are often glued to aluminum sheet metal parts, which convey the heat from the cell surface to cold plates on the sides. Here thermal conductive pastes are very widespread, and recovery of undamaged cells is almost impossible.

3. The welding of cell tabs, usually by ultrasonic or laser welding, poses a challenge to the non-destructive separation, as the tabs are about $0.2-0.3 \mathrm{~mm}$ thick. They are either welded one to another, or by intermediate busbars. In both cases, after the separation, the surface is not suited anymore for a new joint, and the tabs are too short to be used again

In the LiVe-project, sponsored by the German Ministry of the Environment, a module for a heavy-duty delivery truck has been proposed (Fig. 16), with the purpose to be easy to manufacture and disassemble, as well as to provide the maximum useful life to its cells.

Specific design for remanufacturing has been proposed with the following features:

1. No glue has been used, instead the cells are positioned during the stacking by the cell connection system, made by different cell frames. Moreover, the cell frames have the 


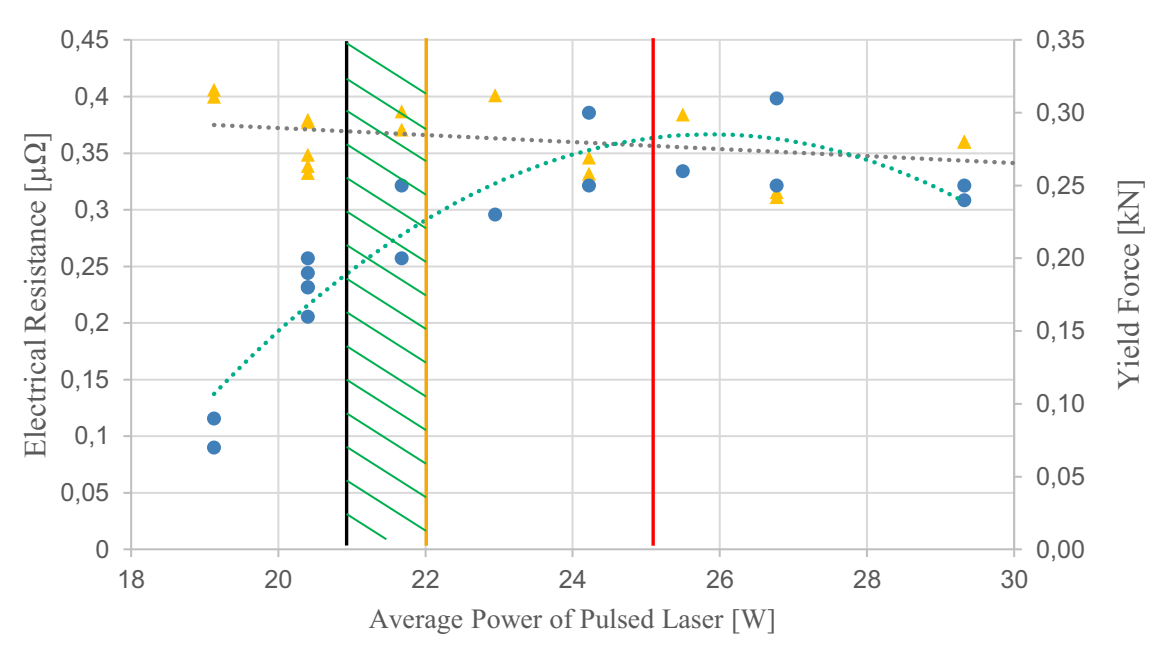

$\triangle$ Electrical resistance Pulling force

Increasing the average power of the pulsed laser, the electrical resistance decreases slowly, while the required pulling force to separate the current collector increases steeply up to a maximum, after which the intermetallic phases make the joint more fragile. A power above $25 \mathrm{~W}$ causes an inacceptable increase in the cells temperature, while the region between the black and

the yellow lines allows to separate the joints without damaging the cells, with a very good electrical resistance.

Fig. 15 Relation between electrical resistance, yield force, and laser power Increasing the average power of the pulsed laser, the electrical resistance decreases slowly, while the required pulling force to separate the current collector increases steeply up to a maximum, after which the intermetallic phases make the joint more fragile. A power above $25 \mathrm{~W}$ causes an inacceptable increase in the cells temperature, while the region between the black and the yellow lines allows to separate the joints without damaging the cells, with a very good electrical resistance

function for the positioning of the cell tabs and bending them into a shape for laser welding as well as remanufacturing. The cell frame give the stack height and the cells are positioned on gap pads, which compensate the tolerances and adsorb the swelling due to the state of charge, as well as to the cells aging. The cell cooling is mainly realized by the cells tabs, which have a larger contact area to the cold plate as the one needed for cell contacting only. [12] This prolongs cells life because of more temperature homogeneity in the cells [13]

2. The extra length of the formed cell tabs allows them to be cut and still be long enough for a second life contacting, using different cell frames, which is shown in Fig. 17. The cell contacting frames have a groove to catch the molten metal ejected by the laser cutting operation while remanufacturing.

This design has been proved to withstand remanufacturing on small scale demonstrator, and it is currently being built and tested, as far as the effectiveness of the cooling system is regarded. 


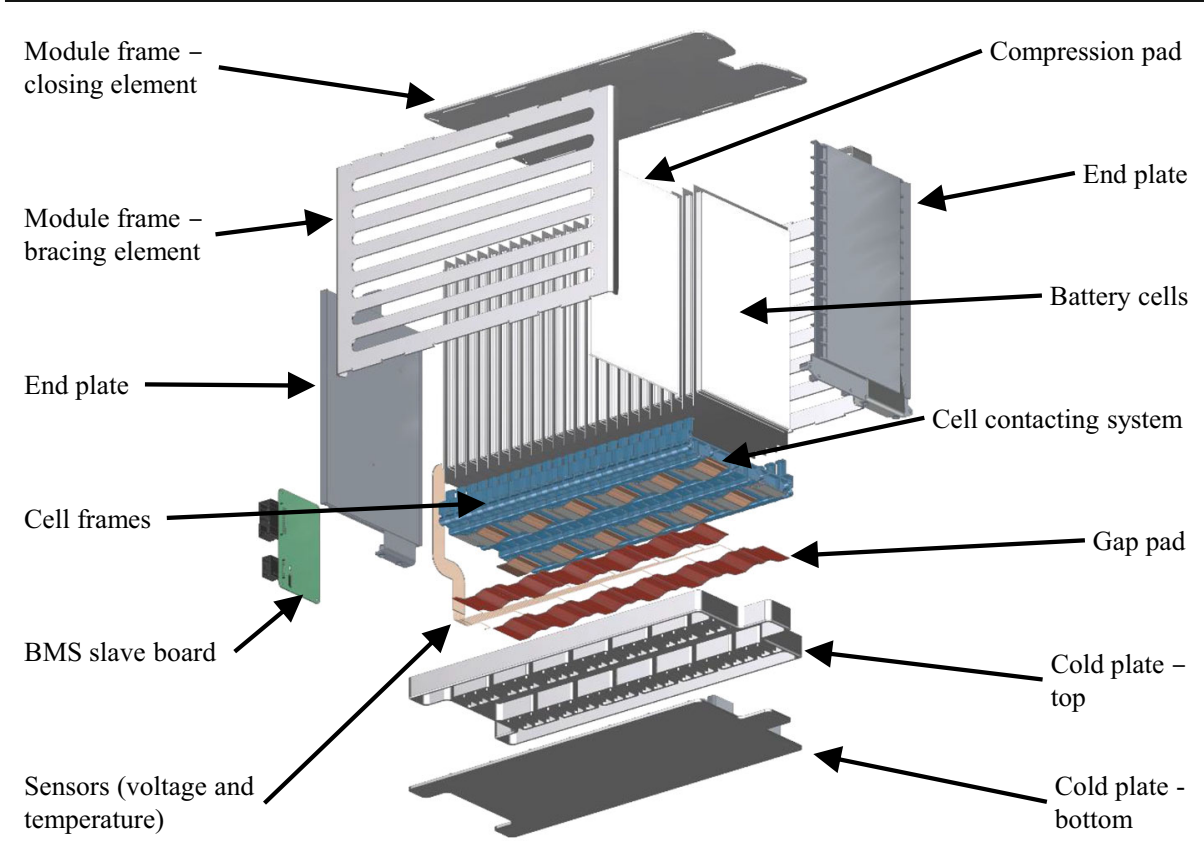

The module has tab cooling, in order to avoid thermally conductive paste on the cells surfaces and on the module walls: the heat is exchanged from the cell tabs to the cold plate through a gap pad. The cell tabs are formed by the plastic cell frames during cell stacking. In principle, all steps can be automated.

Fig. 16 Pouch battery module for the LiVe project truck The module has tab cooling, in order to avoid thermally conductive paste on the cells surfaces and on the module walls: the heat is exchanged from the cell tabs to the cold plate through a gap pad. The cell tabs are formed by the plastic cell frames during cell stacking. In principle, all steps can be automated

\section{Discussion}

The present work shows that the potential of battery remanufacturing can be only fully harnessed if the batteries are disassembled up to single cells, which are then sorted by its quality. This changes the perspective from the maintenance of a single core in a functioning state corresponding to the original product specifications, to the best possible use of available battery cells. This change of perspective opens new challenges for the traceability of incoming cores and of their cells over multiple lifecycles, so that the single cells, are to be considered as cores, around which the whole process of sorting, reusing and repurposing is tailored.

The testing procedures at cell level can be very long and require expensive equipment, so some research is needed in reducing the testing time to achieve a meaningful sorting of the cells. In particular, the feasibility of a two stage testing approach where the first inspection is at module level, aimed at identifying the difference among single cells and the presence of fast degradation mechanisms by impedance spectroscopy needs to be validated outside of laboratory conditions. [5]

The processes of laser welding of cells and separating cells by mechanical or laser cutting means, as well as the handling of used cells, which might have incurred damage and thus lost electrolyte, pose a huge safety question. One way that the proposed module designs fulfill the requirement to be easy to both assemble and disassemble is that they have one side with cell 


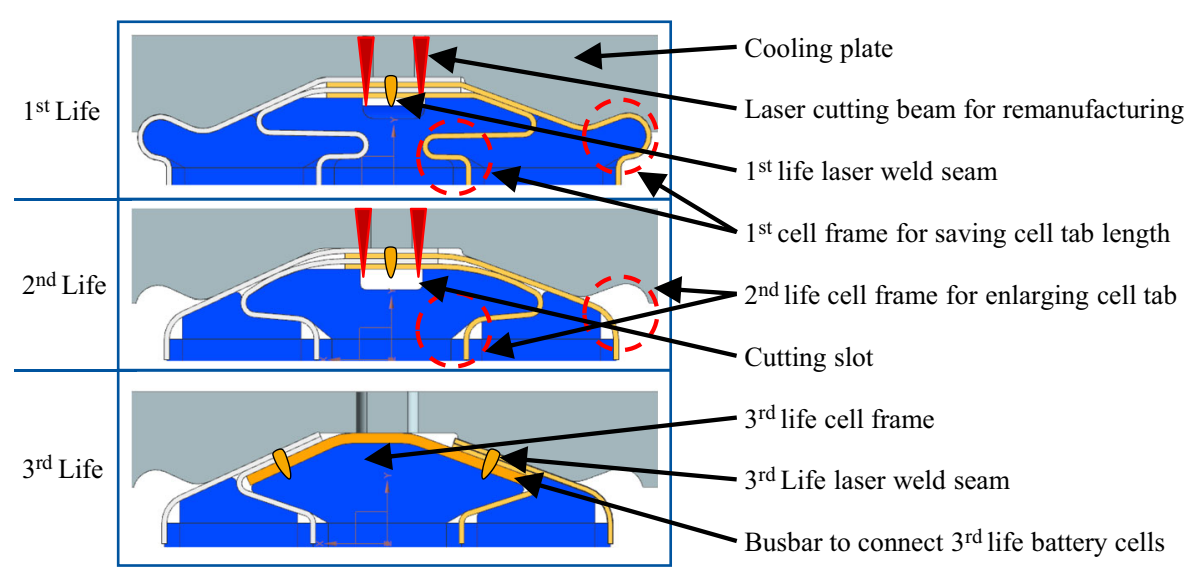

The plastic cell frames form the tabs during cell stacking. After the cut during disassembly, the tabs are shorter than initially. For $2^{\text {nd }}$ and $3^{\text {rd }}$ life application, life specific plastic cell frames need to be used to ensure enough overlapping weld seam space for cell welding. The third time the cells are repurposed, an additional busbar must be added, and the available surface for tab cooling is sufficient only for a low power application, which is compatible with the increase in internal resistance of used cells.

Fig. 17 Pouch cell tab contacting systems at different stages of the lifecycle The plastic cell frames form the tabs during cell stacking. After the cut during disassembly, the tabs are shorter than initially. For 2nd and 3rd life application, life specific plastic cell frames need to be used to ensure enough overlapping weld seam space for cell welding. The third time the cells are repurposed, an additional busbar must be added, and the available surface for tab cooling is sufficient only for a low power application, which is compatible with the increase in internal resistance of used cells

connectors, where mishandling by a human operator might accidentally cause a short circuit, which would result in danger for workers and loss of equipment and long downtime. Likely, the implementation of these remanufacturing processes at cell level makes only sense with a high degree of automation, and opens new research questions for the fields of robotics and human-robots-collaboration, such as the mapping of and working in a potentially dangerous environment in an unknown state, such as a used battery. Moreover, some active safety measure must be investigated to prevent the loss of expensive equipment in case of thermal runaway or loss of electrolyte.

Each of the three proposed designs has advantages and disadvantages regarding the reuse of cells: considering that the testing of every cell format takes the same time, cells with little capacity such as round cells are the least valuable to be recovered; prismatic and pouch cells are bigger, so inherently more valuable to be recovered. While pouch cells, and especially their tabs, are more delicate to handle than prismatic ones, but both cells can be handled with current technology.

\section{Conclusions}

The potential for remanufacturing of Lithium Ion batteries is very high, as most of the value of battery packs can be technically recovered. This work shows that the batteries need to be disassembled and tested up to cells level, in order to recover this potential value, and showed some technical difficulties in such a disassembly operation. Examples on how to overcome 
these difficulties by implementing appropriate design for remanufacturing strategies have also been proposed, hand have been shown not to be detrimental to any product requirement. Some further research is needed in order to recover wiring harnesses and FlexPCBs, which are used to measure cells voltages and temperature.

Nevertheless, their impact on remanufacturing cost must be estimated on the basis of automatized production technologies, capable of scaling to industrially relevant quantities, and the safety problems of operating a disassembly line must be solved. Further research is needed to implement remanufacturing at reasonable costs for industrial applications, especially in the fields of automation and tests on both incoming cores, as well on remanufactured batteries.

Acknowledgements This work would have not been possible without the support and help of the Chair of Production Engineering of E-Mobility Components (PEM) of RWTH-Aachen University and its network of engineering partners.

Special acknowledgements are for: Christoph Lienemann, Sarah Fluchs, and Ansgar Hollah, who opened the way for research in remanufacturing at the institute, for the chief engineer Dr--Ing. Heiner Heimes, for his supervision and for making the resources available, for the E-Lab and our technicians, Dirk Fischer, Fabian Kawollek and Daniel Pelzer, for Dr. Jens Bockstette and his company Futavis and for Simon Britten.

The possibility of performing the laser welding and cutting experiments at the Ramp-up Factory of RWTH Aachen University is highly appreciated.

Authors' contributions Prof. Dr.-Ing. Achim Kampker is founder of the Chair of Production Engineering of EMobility Components (PEM) of RWTH Aachen University, and started the research on battery remanufacturing.

Saskia Wessel, M. Sc. is Chief Engineer of the Powertrain Division of the Chair of Production Engineering of E-Mobility Components (PEM) of RWTH Aachen University and expert of battery testing and homologation.

Falko Fiedler, M. Sc. is group lead Body Shop at the Laboratory for Machine Tools and Production Engineering (WZL) of RWTH Aachen University and expert of joining and cutting technologies. He helped the project with his insights about cell as well as module contacting and the best ways to separate them.

Dipl.-Ing. Francesco Maltoni is Research Associate in the Battery Engineering Group of the Chair of Production Engineering of E-Mobility Components (PEM) of RWTH Aachen University. He took part in the BatteReMan project where he performed practical research on battery disassembly as well developed designs for remanufacturing of battery systems. Furthermore, he is currently working on the LiVe project, where some of these concepts are being validated from a functional and economical point of view.

Funding information Open Access funding provided by Projekt DEAL. More thanks for the project funding to the European Fund for Regional Development and German Ministry of the Environment, as well as the project partners Futavis, StreetScooter, Deutsche Post, and Isuzu.

Open Access This article is licensed under a Creative Commons Attribution 4.0 International License, which permits use, sharing, adaptation, distribution and reproduction in any medium or format, as long as you give appropriate credit to the original author(s) and the source, provide a link to the Creative Commons licence, and indicate if changes were made. The images or other third party material in this article are included in the article's Creative Commons licence, unless indicated otherwise in a credit line to the material. If material is not included in the article's Creative Commons licence and your intended use is not permitted by statutory regulation or exceeds the permitted use, you will need to obtain permission directly from the copyright holder. To view a copy of this licence, visit http://creativecommons.org/licenses/by/4.0/.

\section{References}

1. (2000) Directive $2000 / 53 / \mathrm{EC}$ on end-of life vehicles

2. (2003) DIN 8593-0. Fertigungsverfahren Fügen(8593) 
3. (2008) Directive 2008/98/EC on Waste

4. Barré A, Deguilhem B, Grolleau S, Gérard M, Suard F, Riu D (2013) A review on lithium-ion battery ageing mechanisms and estimations for automotive applications. J Power Sources 241:680-689. https://doi. org/10.1016/j.jpowsour.2013.05.040

5. Becker J, Beverungen D, Winter M et al. (eds) Umwidmung und Weiterverwendung von Taktionsbatterien. Szenarien, Dienstleistungen und Entscheidungsunterstützung

6. Brand MJ, Schmidt PA, Zaeh MF, Jossen A (2015) Welding techniques for battery cells and resulting electrical contact resistances. J Energy Storage 1:7-14. https://doi.org/10.1016/j.est.2015.04.001

7. Cannarella J, Arnold CB (2014) Stress evolution and capacity fade in constrained lithium-ion pouch cells. J Power Sources 245:745-751. https://doi.org/10.1016/j.jpowsour.2013.06.165

8. Das A, Li D, Williams D, Greenwood D (2018) Joining Technologies for Automotive Battery Systems Manufacturing. WEVJ 9(2):22. https://doi.org/10.3390/wevj9020022

9. Elektrische Kontakte, Werkstoffe und Anwendungen

10. Förster R (2018) Einführung in die Fertigungstechnik

11. Galeotti M, Cinà L, Giammanco C, Cordiner S, di Carlo A (2015) Performance analysis and SOH (state of health) evaluation of lithium polymer batteries through electrochemical impedance spectroscopy. Energy 89:678-686. https://doi.org/10.1016/j.energy.2015.05.148

12. Heimes H, Kempker A, Mohsseni A et al. Cell Tab Cooling System for Battery Life Extension. In print. In: 2019 18th IEEE Intersociety Conference on Thermal and Thermomechanical Phenomena in Electronic Systems (ITherm). IEEE

13. Hunt IA, Zhao Y, Patel Y, Offer J (2016) Surface cooling causes accelerated degradation compared to tab cooling for Lithium-ion pouch cells. J Electrochem Soc 163(9):A1846-A1852. https://doi.org/10.1149 /2.0361609jes

14. Jan Philipp Schmidt Verfahren zur Charakterisierung und Modellierung von Lithium-Ionen Zellen

15. Jansen T, Blass D, Hartwig S, Dilger K (2018) Processing of advanced battery materials - laser cutting of pure Lithium metal foils. Batteries 4(3):37. https://doi.org/10.3390/batteries4030037

16. Johnson MR, McCarthy IP (2014) Product recovery decisions within the context of extended producer responsibility. J Eng Technol Manag 34:9-28. https://doi.org/10.1016/j.jengtecman.2013.11.002

17. Kampker A (2016) Evaluation of a remanufacturing for Lithium ion batteries from electric cars. World Acad Sci Eng Technol 3(12)

18. Kampker A (2019) Laserstrahlgeschweißte Batteriepackgehäuse für Elektrofahrzeuge. ATZ Worldwide: 74-78

19. Kampker A, Heimes H, Lienemann $\mathrm{C}$ et al. Development of a novel remanufacturing architecture for lithium-ion battery packs. In: 2017 Electric Vehicles International Conference (EV), pp 1-6

20. Kerr W, Ryan C (2001) Eco-efficiency gains from remanufacturing. J Clean Prod 9(1):75-81. https://doi. org/10.1016/S0959-6526(00)00032-9

21. Kronthaler MR, Schloegl F, Kurfer J, Wiedenmann R, Zaeh MF, Reinhart G (2012) Laser cutting in the production of Lithium ion cells. Phys Procedia 39:213-224. https://doi.org/10.1016/j.phpro.2012.10.032

22. Lee SS, Kim TH, Hu SJ et al. (2010) Joining Technologies for Automotive Lithium-Ion Battery Manufacturing: A Review. In: ASME 2010 International Manufacturing Science and Engineering Conference, Volume 1. ASMEDC, pp 541-549

23. Lehner S Reliability assessment of lithium-ion battery systems with special emphasis on cell performance distribution. Dissertation, RWTH Aachen; Shaker Verlag GmbH

24. Lienemann C (2016) Evaluation of a remanufacturing for Lithium ion batteries from electric cars, Sydney

25. Mathew M, Kong QH, McGrory J, Fowler M (2017) Simulation of lithium ion battery replacement in a battery pack for application in electric vehicles. J Power Sources 349:94-104. https://doi.org/10.1016/j. jpowsour.2017.03.010

26. Matsumoto M, Yang S, Martinsen K, Kainuma Y (2016) Trends and research challenges in remanufacturing. Int J of Precis Eng and Manuf-Green Tech 3(1):129-142. https://doi.org/10.1007 /s40684-016-0016-4

27. Office P (2006) Directive 2006/66/EC on batteries and accumulators and waste batteries and accumulators and repealing directive 91/157/EEC. Batteries directive (2006/66/EC)

28. Rohr S, Müller S, Baumann M, Kerler M, Ebert F, Kaden D, Lienkamp M (2017) Quantifying uncertainties in reusing Lithium-ion batteries from electric vehicles. Procedia Manufacturing 8:603-610. https://doi. org/10.1016/j.promfg.2017.02.077

29. Schmidt P (2015) Laserstrahlschweißen elektrischer Kontakte von Lithium-Ionen-Batterien in Elektro- und Hybridfahrzeugen. Dissertation, Technische Universität München

30. Singer R, Fleischer J (2018) Demontagegerechtes Batteriemodul. ATZ Automobiltech Z 120(1):100-103

31. Singer R, Fleischer J (2018) Demountable battery module. ATZ Automobiltech Z 120(1):80-83 
32. Smith VM, Keoleian GA (2004) The value of remanufactured engines: life-cycle environmental and economic perspectives. J Ind Ecol 8(1-2):193-221. https://doi.org/10.1162/1088198041269463

33. Subramoniam R, Huisingh D, Chinnam RB, Subramoniam S (2013) Remaufacturing decision-making Framwork: research validation using the analythical hierarchical process remanufacturing decision-making framework (RDMF) // remanufacturing decision-making framework (RDMF). Res Valid Using Analytical Hierarchical Process J Cleaner Product 40:212-220. https://doi.org/10.1016/j.jclepro.2011.09.004

34. Sundin E (2004) Product and process design for successful remanufacturing. Zugl.: Linköping, Univ., Diss., 2004. Linköping studies in science and technology dissertation, vol 906. Univ, Linköping

35. Sundin E, Lindahl M (2008) Rethinking product design for remanufacturing to facilitate integrated product service offerings. Electronics and the environment: 1-6. doi: https://doi.org/10.1109/ISEE.2008.4562901

36. Toffel MW (2004) Strategic Management of Product Recovery. Calif Manag Rev 46(2):120-141. https://doi.org/10.2307/41166214

37. US2015093611A1

38. Vetter J, Novák P, Wagner MR, Veit C, Möller KC, Besenhard JO, Winter M, Wohlfahrt-Mehrens M, Vogler C, Hammouche A (2005) Ageing mechanisms in lithium-ion batteries. J Power Sources 147(1-2): 269-281. https://doi.org/10.1016/j.jpowsour.2005.01.006

39. Wang H (2017) Selective disassembly planning for end of life product

40. WO2015016979A1

41. Yilbas BS (2018) Some applications of laser cutting. In: The Laser Cutting Process. Elsevier, pp 205-297

42. Zhou Z, Liu J, Pham DT et al (2018) Disassembly sequence planning: recent developments and future trends. Proceed Inst Mech Eng, Part B: J Eng Manuf 18(4):095440541878997. https://doi.org/10.1177 /0954405418789975

Publisher's note Springer Nature remains neutral with regard to jurisdictional claims in published maps and institutional affiliations. 